\title{
ПРОДУКТИВН ЯКОСТІ СВИНОМАТОК ТА ЇХНЬОГО ПОТОМСТВА ЗАЛЕЖНО ВІД ТРИВАЛОСТІ ПІДСИСНОГО ПЕРІОДУ
}

Повод Микола Григорович

доктор сільськогосподарських наук, професор Сумський національний аграрний університет ORCID: 0000-0001-9272-9672/ W-1565-2018

E-mail: nic.pov@ukr.net

Швачка Руслан Петрович аспірант спец. 204 - ТВППТ

Сумський національний аграрний університет ORCID: 0000-0001-7185-4343/ F-5634-2019

E-mail: ruslans19hvachka@gmail.com

Михалко Олександр Григорович аспірант спец. 204 - ТВППТ

Сумський національний аграрний університет ORCID: 0000-0002-0736-2296/ G-2305-2018

E-mail: snau.cz@ukr.net

Юрьєва Катерина Вікторовна студент спец. 204 - ТВППТ Сумський національний аграрний університет ORCID: 0000-0002-1748-1758/ AAD-8366-2020

E-mail: kateureva4@gmail.com

В статті вивчали залежність відтворювальних, відгодівельних, забійних якостей та фізико-хімічних показників м'яса від тривалості підсисного періоду у свиней сучасних інтенсивних генотипів. Встановлено, що скорочення з 28 до 21 доби тривалості лактації призвело до зменшення загальної кількості народжених поросят на 6,28\%, багатоплідності на 7,33\%, маси гнізда поросят при народжені на 5,49\%, середньої маси одного поросяти при відлучені на 23,34\%, маси гнізда в цей період на 17,70\%, абсолютного на 28,57\% та відносного на 11,08 приростів, та підвищення на 1,49\% великоплідності, на 6,34\% збереженості, на 7,34\% кількості поросят при відлучені, на 2,21\% їх середньодобових приростів 8 підсисний період та 6,25\% комплексного показника відтворювальних якостей. Водночас скорочення тривалості лактації свиноматок на 7 діб, збільшило на 5,35\% інтенсивність використання свиноматки, дозволило додатково отримати від неї на 13,95\% ділових поросят, на 25\% інтенсивніше використовувати станкомісце для опоросу, зменшити на 27,25\% щорічні витрати комбікорму та додатково отримати за цей період 1331 грн грошових коштів. Поросята за раннього їх відлучення мали на дорощуванні і початку відгодівлі нижчу на 2,90-11,35\% інтенсивність росту, гіршу на 0,83\% збереженість та на 0,03 ке оплату корму приростами. Не встановлено залежності забійних якостей, вмісту у тушах м'яса, сала та кісток і фізико-хімічних властивостей м'яса від тривалості підсисного періоду. Встановлено їх залежність від передзабійної живої маси.

Ключові слова: свиноматка, порося, приріст, багатоплідність, збереженісь, витрати корму, інтенсивність використання.

DOl: https://doi.org/10.32845/bsnau.lvst.2019.4.11

Продовольчу безпеку України забезпечує, головним чином, галузь свинарства, попит на продукцію якої в споживанні м'яса становить $35 \%$. Скорочення кількості дрібних виробників свинини надало змогу швидкому розвитку великих підприємств з високим технологічним забезпеченням і впровадженням нових виробничих технологій [9, 22]. Одним 3 найважливіших елементів в технологічному процесі виробництва свинини $€$ термін відлучення поросят. Світова тенденція схиляється до скорочення підсисного періоду. Так, в США поросят відлучають у 14 денному віці, в окремих країнах Європи в 21 день, в Англії - 25, Данії - 28, Канаді 14-16 днів [31, 34]. Розвиток генетики, біохімії, фізіології та інших наук, а також застосування останніх досягнень в технології виробництва комбікормів з добавками ферментів, антибіотиків, біологічно активних речовин дозволило скоро- тити термін відлучення поросят до трьох тижнів $[6,8]$.

Подальше скорочення підсисного періоду до 3 тижнів $€$ ще одним фактором ризику для життя свиноматки і вимагає розробки спеціальних заходів і досконалого менеджменту [33]. Скорочення підсисного періоду під час першого опоросу негативно впливає на тривалість використання свиноматок. При тривалості підсисного періоду від 17 до 21 днів їх вибракування виявилося майже в два рази більшим, ніж при відлученні поросят після 4-х тижнів [25].

Перевага раннього відлучення в тому, що воно безпосередньо впливає на тривалість лактації свиноматок. Свиноматці необхідно приблизно 14 днів для відновлення наслідків вагітності до того стану, коли можлива наступна. Як зауважують в своїй роботі T. Whiting та Т. Pasma [36], скорочення терміну лактації сприяє більш повільному при- 
ходу в охоту, зниження кількості поросят в гнізді. Водночас, зниження тривалості лактації з 30 до 17 днів, за їх даними, не впливає на кількість поросят, отриманих від однієї свиноматки в рік.

Відлучення поросят в промислових умовах у віці 2-3 тижнів викликає стресовий стан, при якому тваринам важко адаптуватися до нового раціону, до зміни екологічного та соціального середовища. Внаслідок даних процесів спостерігається зниження рівня споживання корму відразу після відлучення, і поросята недоотримають відповідну кількість енергії [29,30, 32, 33 36]. Як стверджують J. M. Campbell, J. D. Crenshaw та J.Polo [28], поросята втрачають 100-250 г живої маси в перший день після відлучення, незалежно від тривалості підсисного періоду, і відновлюють цю втрату лише на четвертий день.

Раннє відлучення поросят дозволяє використовувати свиноматку більш інтенсивно завдяки скороченню відтворювального циклу, що в свою чергу забезпечує отримання від неї в середньому більш ніж два опороси на рік. Відлучені поросята, за повідомленнями П.П. Антоненко, А.Н. Свежицева та Д.Н. Масляка [1], починають раніше споживати рослинну їжу і, як наслідок, у них підвищуються середньодобові прирости живої маси при зниженні собівартості корму. Іншої думки дотримуються в своїх дослідженнях D.L. Turpin, P. Langendijk, T.Y. Chen, J.R. Pluske [35], які стверджують, що збільшення тривалості підсисного періоду призводить до того, що поросята починають споживати більше кормів після відлучення і знижується рівень стресу, але існує велика ймовірність негативного впливу на відтворну функцію свиноматок.

За даними академіка А. В. Квасницького $[18,26]$, тривалий підсисний період веде до виснаження маток i погіршення їх відтворювальних якостей в порівнянні з раннім відлученням поросят. Встановлено, що зменшення тривалості лактації супроводжується збереженням маси тіла свиноматки. Раннє відлучення поросят надає змогу здійснити більш раннє осіменіння для отримання наступного опоросу, з'являється можливість отримувати 2,5 опоросу і 30 поросят від кожної свиноматки в рік $[11,27]$.

3 іншого боку, скорочення термінів відлучення не дозволяє в повній мірі використовувати високу молочну продуктивність свиноматки, яка продукує в цей період лактації 7-8 кг молока на добу. Відсутність повноцінних легкоперетравних і добре засвоюваних кормів, збалансованих за всіма поживними речовинами і елементам харчування, призводить до уповільнення росту, розвитку, захворювань і загибелі поросят [10].

Поросята відлученні від свиноматок до 35-денного віку, за даними E. Worobec end I. Duncan [37], мають проблеми під дією екстремальних факторів, якими є відлучення і формування груп, що не забезпечує підтримку гомеостазу, та приводить на початку до підвищення, а потім до порушення функцій систем та обміну речовин. Все це, на думку V. Colson [29], обумовлює зниження загальної резистентності організму, виникнення захворювань і великого відсотку загибелі тварин, що спостерігається в комплексах при відлученні поросят в 21 - і 26-денному віці

Зміни в середовищі, які спостерігаються під час відлучення, викликають адаптаційні зміни в поведінці та фізіології поросят внаслідок зміни корму, що приводить до зменшення середньодобових приростів ваги. Щоденний приріст зменшується при відлученні у 21 або 28 днів. Але інтенсивність і тривалість даного процесу більша у поросят 3 тривалістю підсисного періоду 21 день [17,30].

Перевагою раннього відлучення поросят $є$ зменшення фізіологічного навантаження внаслідок короткого підсисного періоду в порівнянні із звичайним. Свиноматки, протягом двох місяців підсисного періоду втрачають до 40-50 кг живої маси і в результаті приходять в охоту протягом 2-3 місяців. Для відновлення кондицій свиноматка повинна спожити додатково 1-1,5 кг корму. За раннього відлучення поросят використання одного станка збільшується в 2 рази [14].

Збільшення рентабельності виробництва свинини в умовах промислового виробництва відбувається завдяки скороченню терміну підсисного періоду, що впливає на ріст і збереженість поголів'я поросят [24]

Мета роботи полягала у вивченні впливу різних термінів підсисного періоду (28-21 доба) на відтворювальні якості свиноматок, ріст поросят в період дорощування та відгодівлі, відгодівельні, забійні якості та якісні показники м'яса.

Матеріали та методи досліджень. Матеріалом для дослідження слугували продуктивні якості свиноматок та ріст поросят і відгодівельні, забійні та м'ясо-сальні якості за різних термінів підсисного періоду - (28 діб контрольна група та 21 доба дослідна група).

Дослідження проводилося упродовж січня-вересня 2019 року на базі репродуктору № 2 Обізнівка, цеху дорощування поросят №2 Демидівка, цеху відгодівлі свиней №3 Гриньки ТОВ «НВП «Глобинський свинокомплекс» та Глобинського м'ясокомбінату. Для дослідження за методом пар аналогів було сфрормовано дві групи свиноматок $F_{1}$, від ірландського йоркшира та ірландського ландраса, в кількості 60 голів кожна, яких осіменили спермою кнурів синтетичної термінальної лінії «MaxGrow» селекції ірландської фрірми Hermitage Genetics. У холостий і поросний періоди свиноматки утримувалися за ідентичних умов, параметрів мікроклімату і були забезпечені повноцінним, збалансованим раціоном.

Під час опоросу свиноматки утримувались в ідентичних секціях цеху опоросу. Поросята дослідної групи були відлучені від свиноматок з середнім віком 21 добу і переведені на дорощування в цех № 2 Демидівка. Через 7 діб туди ж були переведені тварини контрольної групи. Під час підсисного періоду визначали наступні показники: загальну кількість народжених поросят, багатоплідність (кількість живих поросят при народженні), масу гнізда при народженні, великоплідність, кількість поросят при відлученні, збереженість, індивідуальну живу масу і масу гнізда при відлученні. Інтенсивність росту поросят вивчали за абсолютними, середньодобовими і відносними приростами живої маси.

Для комплексної оцінки відтворювальних якостей свиноматок, за різної тривалості підсисного періоду, використовували оціночний індекс конструкції М.Д. Березовського [4]:

$$
I=B+2 W+35 G
$$

де В - кількість поросят при народженні , голів;

W - кількість відлучених поросят, голів;

G - середньодобовий приріст поросят до відлучення,

Кг; 
На дорощуванні поросят обох груп утримували в ідентичних умовах, у суміжних станках площею 45 м² кожний по 140 голів на частково ґратчастій підлозі 3 підігрівом суцільної іï частини. В яких подача води здійснювалась по 12 ніпельних автонапувалках. Транспортування корму та годівля здійснювались індивідуально на кожний станок 3 електронними його обліком за допомогою системи порційної годівлі Spotmix II австрійської фрірми Schauer. Усі поросята годувались повнораціонними комбікормами виробництва власного комбікормового заводу. Згідно схеми прийнятої у господарстві, з 7 по 41 добу годівля здійснювалась престартерними комбікормами з поступовим переходом з 42 по 46 добу на годівлю стартерними і з 72 по 77 добу на годівлю гроверними комбікормами.

Під час вивантаження корму з системи трубопроводів у годівницю він зволожується до чітко заданої вологості за допомогою спеціальних форсунок високого тиску. Вологість корму регулюється у широких межах за допомогою комп'ютерної системи управління.

Подача корму здійснюється порціями у металеві годівниці через певні, задані програмою, проміжки часу. Після задавання корму упродовж чотирьох секунд проводиться промивка кормопроводу чистою водою під тиском. Кількість корму в годівницях регулюється залежно від швидкості його поїдання тваринами. Система підтримки мікроклімату, водонапування, видалення гною для тварин усіх груп була ідентичною.

Тварин обох груп переважували при переведенні 3 престартерного на перший стартений комбікорм у віці 41 діб, при переведенні з першого стартеру на другий у віці 56 діб та при відвантажені на відгодівлю. Витрати корму на кожний станок та на кожне порося враховувались комп'ютером системи Spotmix II. Щоденно враховувались кількість поросят, що вибули. Під час досліду нами вивчались збереженість поросят, інтенсивність росту, середньодобове споживання корму та його конверсія.

По завершенню дорощування поросят, у віці 77 діб після групового зважування, підсвинки були переведені на відгодівельний свинокомплекс в с. Гриньки, де їх утримували по 50-52 голови в ідентичних умовах у суміжних станках розміром 4,1 на 10,0 м з повністю щілинною підлогою.

Відгодовували тварин обох груп з використанням рідкого типу годівлі, за допомогою обладнання австрійської фірми Weda. Корм до годівниць надходив рівномірними порціями 10-14 разів на добу із співвідношення сухого корму до рідкої його фракції як 1 до 2,8. Облік кормів проводили за допомогою комп'ютеру управління кормокухні шляхом щоденного запису виданого корму в кожний станок. Два рази на добу проводився огляд піддослідних тварин з фіксацією хворих та загиблих тварин і їх маси та причини вибуття.

В досліді вивчення відгодівельних якостей піддослідних тварин проводили за відповідними методичними рекомендаціями Інституту свинарства і АПВ НААН. Відгодівельні якості молодняку свиней піддослідних груп оцінювали за такими ознаками: середньодобовий приріст (г); вік досягнення живої маси 100 та 110 кг (діб); витрати кормів на 1 кг приросту (кг) - за загальноприйнятими методиками [5. 12].

При досягненні середньої маси тварин близької до 105 кг, свиней з двох суміжних станків, по одному з кожної групи, індивідуально зважували та записували спреєм масу на їх спині. По закінчені зважування відбирали по 10 голів 3 кожного станка, найближчих до маси 100 кг, і по 10 голів, найближчих до маси 110 кг, ставили їм татуювальним молотком відповідний номер на обох окостах і, для транспортування на м'ясокомбінат, завантажували в окрему секцію скотовозу.

Забій свиней проводили в умовах м'ясопереробного підприємства ТОВ «Глобинський м'ясокомбінат» після 12 годинної голодної витримки. Вивчення забійних та м'ясосальних якостей піддослідних тварин проводили за відповідними методичними рекомендаціями Інституту свинарства і АПВ НААН України [20, 23].

Морфологічний склад туш свиней визначали шляхом обвалювання обох напівтуш з подальшим зважуванням м'яса, сала та кісток. Для проведення фізико-хімічних досліджень м'язової тканини відбирали зразки з найдовшого м'яза спини (m. longisimus dorsi) на рівні 9-12 грудних хребців в охолодженій туші через 24 години після забою. Хімічний аналіз м'язової тканини проводили згідно «Методики оцінки якості свинини за фізико-хімічними показниками» [2, 3, 19, 21]. В сертифікованій лабораторії ТОВ «Глобинський м'ясокомбінат» вивчали показники активної кислотності (pH) на тушах за допомогою портативного pH-метру «LF-Star CPU-Pistole» (Німеччина) через годину $\left(\mathrm{pH}_{1}\right)$ та 24 години після забою $\left(\mathrm{pH}_{24}\right)$. Оцінку фрізико-хімічних показників якості м'язової тканини свиней проводили за методичними рекомендаціями ВАСГНІЛ [12] та згідно ДСТУ ISO 2917-2001 [20]. Колір м'яса за бальною шкалою «Pork Quality Standards» (1999, NPPC). Хімічний аналіз зразків м'яса та кормів проводили за загальноприйнятими методиками [23].

Результати досліду були обраховані біометрично за допомогою прикладних програм Microsoft Office Excel. Достовірність різниці приймали для рівнів значущості $p \leq 0,05$, $p \leq 0,01$ та $p \leq 0,001$.

Результати досліджень. Згідно експериментальних даних встановлена достовірна мінливість за показниками відтворювальних якостей свиноматок (табл. 1). Так, у свиноматок, які мали напередодні скорочений до 21 доби підсисний період, в наступному опоросі народилося на 0,97 голови, або 6,28\% поросят менше. Також вірогідно $(p<0,01)$ на 1,06 голови, або $7,33 \%$ у них виявлено меншу багатоплідність. За великоплідністю суттєвої різниці між тваринами обох груп не встановлено, але простежувалось тенденція до їі збільшення на 1,49 \% в гніздах свиноматок 3 більш короткою попередньою лактацією.

За рахунок більшої кількості поросят у гнізді, вірогідно ( $p<0,001)$ на 1,15 кг або 5,94\% більшою була маса гнізда при народженні у свиноматок контрольної групи, які мали попередню лактацію 28 діб.

В наслідок більш короткого підсисного періоду у свиноматок дослідної групи їх збереженість в цій групі була вірогідно $(p<0,001)$ на $5,4 \%$ вищою і за рахунок чого на момент відлучення у них виявилось на 0,78 голови або 7,34\% $(p<0,05)$ більше поросят в гнізді.

Враховуючі менший на 7 діб термін підсисного періоду у тварин дослідної групи, закономірно меншою у них на 1,8 кг або на 23,34\% ( $<<0,001$ ) була середня маса одного поросяти при відлученні. Що в свою чергу спричинило вірогідно меншу на $17,7 \%$ або 14,51 кг масу гнізда на цей період ( $p<0,001)$.

Вісник Сумського національного аграрного університету 
Тривалість підсисного періоду вплинула і на подальші відтворювальні якості свиноматок. Так свиноматки, в яких попередня лактація була коротша на 7 діб, прийшли в охоту після відлучення поросят на $2,1 \%$ гірше $(p<0,01)$, у них була на $2.41 \%(p<0,05)$ гірша запліднюваність та на $2,06 \%(p<0,01)$ гірший відсоток опоросу.

За даними таблиці 1, той фактор, що поросята дослідної групи мали коротший на 7 діб підсисний період, спричинив нижчий на 1,82 кг або 28,57\% абсолютний приріст $(p<0,001)$ та на $15,60 \%(p<0,001)$ відносний приріст. Водночас, за середньодобовими приростами у них виявилась тенденція до збільшення цього показника на 6,08 г, або 2,21\%, що говорить про високу інтенсивність молоковіддачі свиноматок до третього тижня лактації.

Відтворювальні якості свиноматок та ріст підсисних поросят

Таблиця 1 за різної тривалості підсисного періоду. $\bar{X} \pm S_{\bar{X}}$

\begin{tabular}{|c|c|c|c|c|}
\hline \multirow{2}{*}{ Показники } & \multirow{2}{*}{$\begin{array}{c}\text { I- контрольна } \\
(\mathrm{n}=60) \\
\bar{X} \pm S \bar{x}\end{array}$} & \multirow{2}{*}{$\begin{array}{c}\begin{array}{c}\| \text { - дослідна } \\
(\mathrm{n}=60)\end{array} \\
\overline{\bar{X}} \pm S \bar{x}\end{array}$} & \multicolumn{2}{|c|}{ 土 контрольна - дослідна } \\
\hline & & & абсолютна & $\%$ \\
\hline Всього народилося поросят, гол & $15,43 \pm 0,331$ & $14,46 \pm 0,272$ & 0,97 & 6,28 \\
\hline Багатоплідність, гол & $14,46 \pm 0,294$ & $13,40 \pm 0,261$ & $1,06^{* *}$ & 7,33 \\
\hline Великоплідність, кг & $1,34 \pm 0,032$ & $1,36 \pm 0,028$ & $-0,02$ & 1,49 \\
\hline Маса гнізда при народженні, кг & $19,37 \pm 0,112$ & $18,22 \pm 0,115$ & $1,15^{\star * \star}$ & 5,94 \\
\hline К-ть відлучених поросят від 1 свиноматки, гол & $10,62 \pm 0,23$ & $11,4 \pm 0,24$ & $-0,78^{*}$ & 7,34 \\
\hline Середня маса поросяти при відлученні, кг & $7,71 \pm 0,17$ & $5,91 \pm 0,09$ & $1,8^{* * *}$ & 23,34 \\
\hline Збереженість, \% & $85,06 \pm 0,35$ & $90,46 \pm 0,41$ & $-5,4^{* * \star}$ & 6,34 \\
\hline Маса гнізда при відлученні, кг & $81,83 \pm 1,13$ & $67,32 \pm 1,26$ & $14,51^{\star \star \star}$ & 17,7 \\
\hline Прихід в охоту після відлучення, \% & $78,38 \pm 0,104$ & $76,28 \pm 0,123$ & $2,1^{* * *}$ & 2,68 \\
\hline Запліднюваність після відлучення, поросят, \% & $93,33 \pm 0,447$ & $90,92 \pm 0,354$ & $2,41^{* * *}$ & 2,65 \\
\hline Відсоток опоросу, \% & $95,23 \pm 0,223$ & $93,17 \pm 0,319$ & $2.06^{* * *}$ & 2.16 \\
\hline $\begin{array}{l}\text { Приріст живої маси поросят: } \\
\text { середньодобовий, г }\end{array}$ & $275,35 \pm 0,328$ & $281,43 \pm 0,352$ & $-6,08^{\star \star \star}$ & 2,21 \\
\hline абсолютний, кг & $6,37 \pm 0,254$ & $4,55 \pm 0,282$ & $1,82^{\star * *}$ & 28,57 \\
\hline відносний, \% & $140,77 \pm 0,128$ & $125,17 \pm 0,135$ & $15,60^{\star \star \star}$ & 11,08 \\
\hline Оціночний індекс, балів & 43,34 & 46,05 & $-2,71$ & 6,25 \\
\hline
\end{tabular}

Примітка - $(p<0,05) ; *(p<0,01) ; * * *(p<0,001)$

Оціночний індекс відтворювальних якостей розрахований за методикою М.Д. Березовського [4] показав, що за комплексом ознак свиноматки, які мали скорочений термін лактації виявили відтворні якості на 2,71 бали бо 6,25 \% кращі.

Отже, за результатами вивчення залежності відтворних якостей свиноматок від тривалості лактаційного періоду встановлена вища у свиноматок з тривалістю лактації в 28 діб, загальна кількість народжених поросят на 6,28\%, багатоплідність, на 7,33\% маса гнізда поросят при народжені на $5,49 \%$, середня маса одного поросяти при відлучені на $23,34 \%$, маса гнізда в цей період на $17,70 \%$, вищий абсолютний на 28,57\% та відносний на 11,08 прирости. Водночас свиноматки з 21 добовим підсисним періодом мали вищу на 1,49\% великоплідність, на 6,34\% кращу збереженість і, як наслідок, більшу на 7,34\% кількість поросят при відлучені, на 2,21\% вищі середньодобові прирости поросят в підсисний період та 6,25\% кращий комплексний показник відтворювальних якостей розрахований як оціночний індекс.

За рік від свиноматок контрольної групи отримано 2,43 опороси, що при виході ділових поросят 10,62 склало 25,8 поросяти в рік (табл.1). У дослідній групі від однієї свиноматки отримано 2,56 опоросу на рік, при виході ділових поросят 11,40 їх кількість до відлучення становила 29,4 голів поросят в рік. Різниця в кількості отриманих ділових поросят від однієї свиноматки впродовж року становила 3,6 голови. При ринковій вартості одного кілограма живої маси поросят при відлучені 136 грн вартість одного поросяти контрольної групи складе 1048 (7,71*136) грн. Водночас вартість поросяти дослідної групи склала 804 (5,91*136) грн. Від свиноматки дослідної групи отримуємо за рік поросят на суму 27038 $\left(25,8^{*} 1048\right)$ грн, тоді як від їх аналогів контрольної групи $23638\left(29,4^{*} 804\right)$ грн. Тобто від кожної свиноматки дослідної групи отримуємо продукції в рік менше на 3401 грн.

У той же час, за рік, свиноматка зменшує тривалість підсисного періоду на 18 діб. 3 огляду на середньодобове споживання корму 7,9 кг, загальна його кількість за цей період складе 142 кг. При середній вартості лактаційного комбікорму 8,6 грн/кг, грошові витрати за рік складуть 1223 грн.

Скорочення тривалості підсисного періоду з 28 до 21 діб дозволило більш інтенсивно використовувати кожне станко-місце для опоросу і лактації свиноматок з 10,4 раз на рік до 13,0 або на 25\% більше разів. При вартості обладнання сучасного станкомісця для опоросу свиноматки в 65739 грн та рекомендованому терміну його використання в 5 років, щорічна амортизаційна вартість його складе 13148 грн. Підвищення ефективності його використання на $25 \%$ дасть додатково економію коштів в розмірі 3287 грн.

Щорічна амортизаційна вартість свиноматки складала 1733 грн. При скороченому термінові лактації на одне порося вона становила 60,0 грн, тоді як при 28 добовій 67,2 грн. Тобто зменшення амортизаційних відрахувань на такий основний засіб виробництва як свиноматка складе в рік 212 
грн.

Таким чином, за традиційної для країн Європи та більшості промислових фрерм України, тривалості лактаційного періоду свиноматок в 28 діб додатково отримано продукції на 3401 грн, при цьому на ії отримання витрачено на 4732 грн більше порівняно з більш раннім в 21 добу відлученням поросят. Тобто зменшення на 7 діб тривалості підсисного періоду дозволило додатково отримати в розрахунку на 1 свиноматку 1331 грн в рік.

Тобто, скорочення тривалості лактації свиноматок на 7 діб, з 28 до 21, дозволило збільшити на 0,13 опоросів, або на 5,35\% інтенсивність використання свиноматки, додатково отримати від неї на 3,6 голови (13,95\%), дозволило на $25 \%$ або, 2,6 рази інтенсивність використання станкомісця для опоросу зменшити на 142 кг, або 27,25\% щорічні витрати комбікорму для лактуючих свиноматок та додатково отримати за цей період 1331 грн грошових коштів.

Також нами було досліджено вплив тривалості підсисного періоду на подальший ріст та відгодівельні якості поросят. Нами було прослідковано ріст та відгодівельні якості поросят відлучених в різний вік.

У всі вікові періоди (рис.1), які відповідали переведенням тварин на новий вид корму, що супроводжувався їх груповим зважуванням, тварини, які мали довший (28 діб) підсисний період, все своє подальше життя випереджали за масою своїх аналогів, які були відлучені на 7 діб раніше.

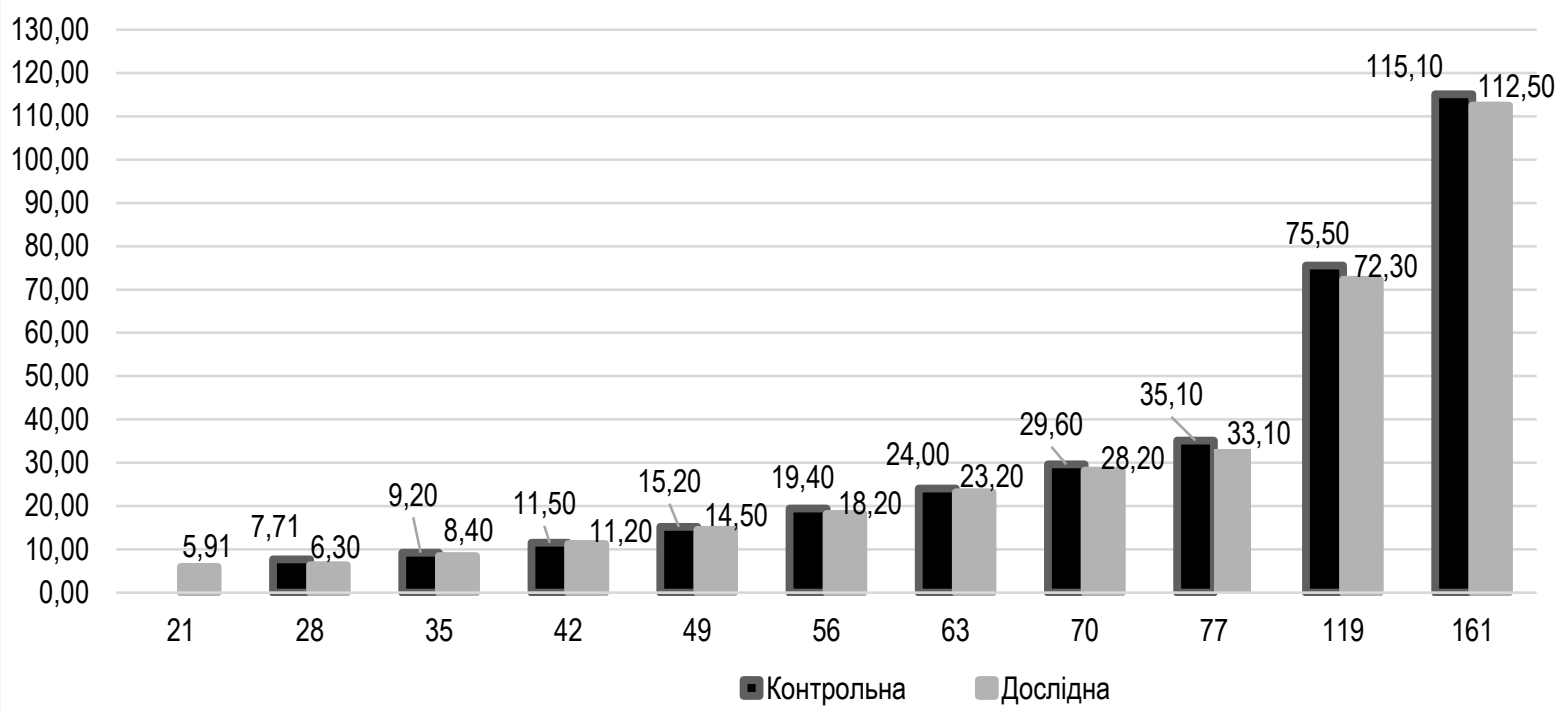

Puc.1. Динаміка збільшення живої маси свиней з різною тривалістю підсисного періоду

Так в віці 28 діб ця різниця склала 1,41кг, у віці 42 діб вона зменшилась до 0,8 кг, в 56 днів - склала 1,2 кг , в 77 днів - 2,0 кг , в 119 днів збільшилась до 3,2 кг, и в віці 161 день склала 2,6 кг.

Як видно з графіку зображеного на рис. 2, усі облікові періоди досліду, за винятком першого періоду дорощування та останнього періоду відгодівлі тварини, які мали більш тривалий підсисний період вирізнялись вищими абсолютними приростами. Але слід врахувати, що перший період дорощування був на 7 діб тривалішим у поросят контрольної групи, тому це перевищення є логічним. В інші періоди до- рощування та перший період відгодівлі абсолютні прирости були вищими у тварин з більш тривалим підсисним періодом. Таке перевищення в період 43-56 діб склало 0,9 кг, в 57-77 діб - 0,8 кг і в 78-119 діб - 1,2 кг. Тоді як в період від 120 по 161 добу абсолютний приріст в цій груп свиней був меншим на 0,6 кг. За весь онтогенез тварини з більш тривалим підсисним періодом приросли більше на 0,8 кг. Тобто не встановлено чіткої закономірності зміни абсолютних приростів за період від відлучення до забою у тварин з різною тривалістю підсисного періоду.

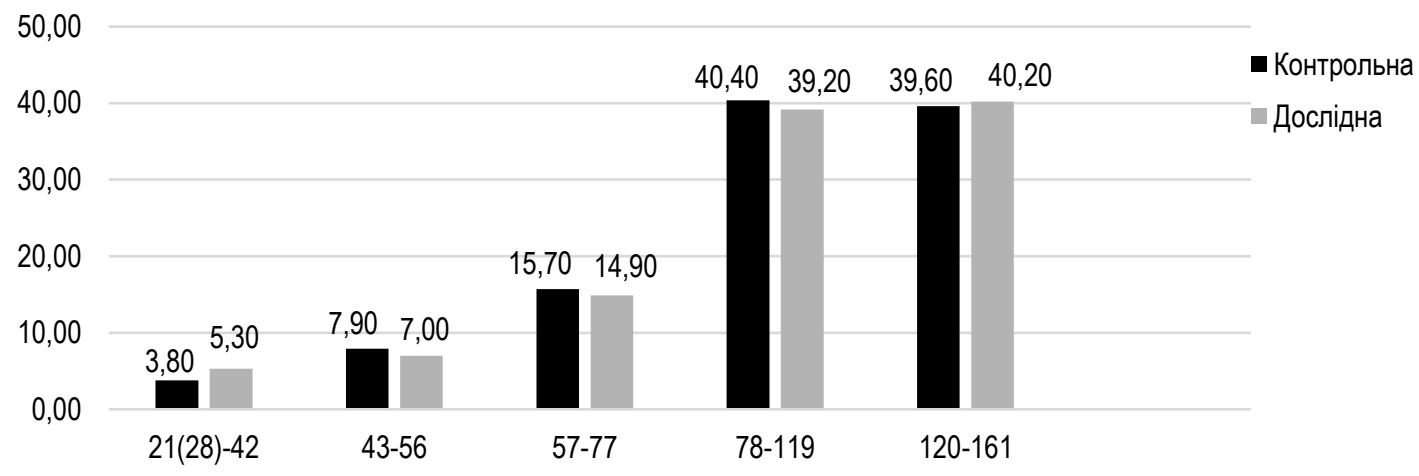

Puс.2. Динаміка зажиттєвих абсолютних приростів свиней з різною тривалістю підсисного періоду 
Тварини дослідної групи (рис.3) за період життя мали на 5,13\% вищі відносні прирости, які по періодам росту

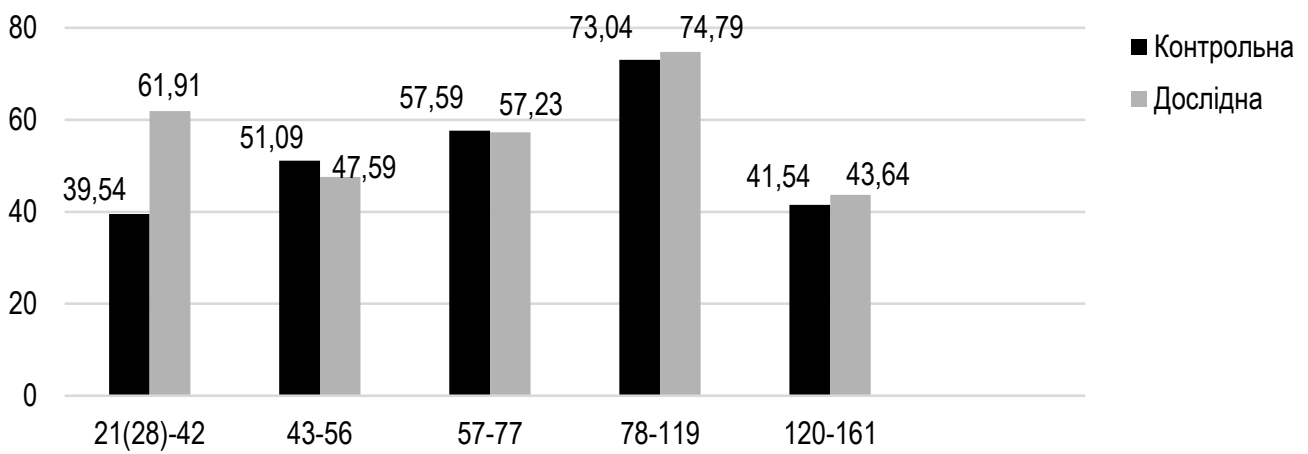

Рuс.3. Динаміка зажиттєвих відносних приростів свиней з різною тривалістю підсисного періоду

В перший період дорощування, через його різну тривалість відносний приріст був вищим на 22,37\% у поросят дослідної групи. Тоді як в період з 43 по 56 добу він виявився на 3,50\% вищим у підсвинків контрольної групи, а в період з 57 по 77 добу практично вирівнявся. В період відгодівлі відносні прирости у свиней дослідної групи вияви- лись вищими - з 78 по 119 добу на - 1,75\%, та з 120 по 161 добу - на 2,10\%.

Середньодобові прирости також були вищими у весь період дорощування, та перший період відгодівлі у поросят 3 більш тривалим на 7 діб підсисним періодом (рис.4).

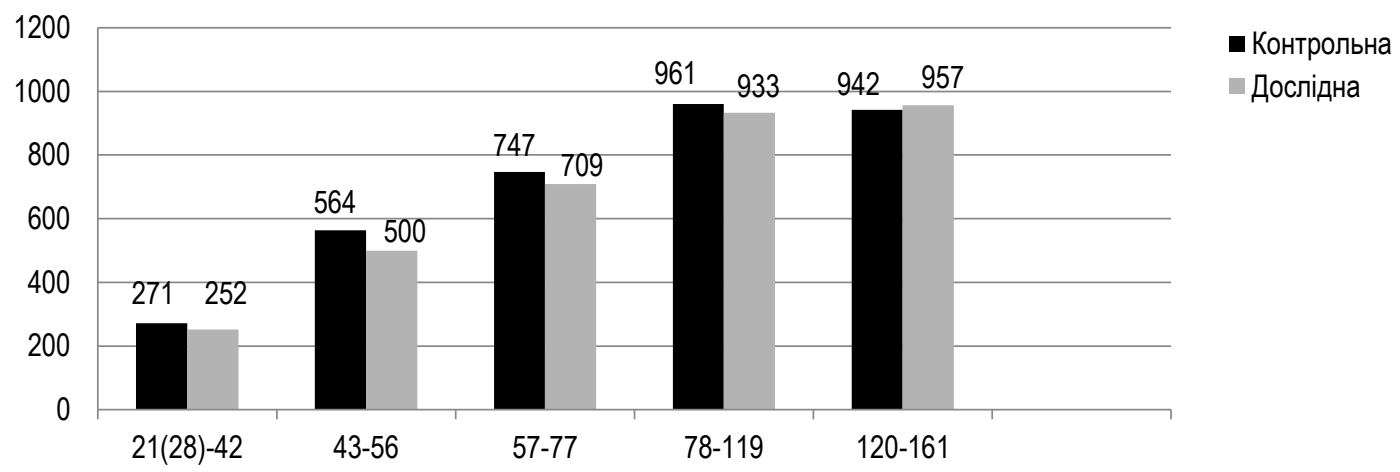

Рuc.4. Динаміка зажиттєвих середньодобових приростів свиней з різною тривалістю підсисного періоду

Так в перший період дорощування преваги тварин контрольної групи за цим показником склали 19 г, (7,01\%), а в період з 43 по 56 добу виросли до 64 г (11,35\%), тоді як 3 57 по 77 добу зменшились до 38 г або 5,09\%. В перший період відгодівлі (78-119 діб) поросята з більш тривалим підсисним періодом переважали своїх ровесників 3 контрольної групи за середньодобовими приростами на 28 г $(2,19 \%)$ тоді я у другий період ( 120-161 доба) поступалися їм за цим показником на 15 г або 159\%. В цілому за період від народження до 161 доби поросята, які були відлучені від свиноматок в 28 діб мали вищий на 5г середньодобовий приріст і як наслідок в цьому віці приросли на 0,8 кг більше.

Вибуття поросят під час дорощування та відгодівлі також залежали від тривалості підсисного періоду. Поросята з більш тривалим підсисним періодом (таблиця 2) після відлучення мали неоднакову частку тих, які вибули.

Таблиия 2

Збереженість свиней під час дорощування та відгодівлі за різної тривалості підсисного періоду

\begin{tabular}{|c|c|c|c|c|}
\hline \multirow{2}{*}{ Період, діб } & \multicolumn{4}{|c|}{ Вибуло свиней } \\
\cline { 2 - 5 } & \multicolumn{2}{|c|}{ контрольна група } & дослідна група \\
\cline { 2 - 5 } & голів & 1,88 & 16 & \multicolumn{2}{c|}{ голів } \\
\hline $21(28)-42$ & 12 & 1,10 & 9 & 1,41 \\
\hline $43-56$ & 7 & 0,47 & 3 & 0,45 \\
\hline $57-77$ & 3 & 3,45 & 28 & 4,22 \\
\hline Всього за період дорощування & 22 & 1,10 & 8 & 1,21 \\
\hline $78-119$ & 7 & 0,79 & 5 & 0,75 \\
\hline 120-161 & 5 & 1,88 & 14 & 2,11 \\
\hline Всього за період відгодівлі & 12 & 5,34 & 41 & 6,17 \\
\hline Всього за період дорощування і відгодівлі
\end{tabular}

Так за період дорощування в контрольній групі вибуло 22 голови, що становило $3,45 \%$ в той же час в дослідній цей показник виявився на 0,77\% вищим. Найбільша частка поросят, що вибула в обох групах склала в перший період дорощування, зразу ж після вилучення їх від свиноматок. Тут також відхід був вищим на 0,53\% серед тварин дослідної 
групи. Аналогічна тенденція проявилась і в другий період дорощування під час годівлі першим стартерним комбікормом. В цей період частка поросят, що вибула в дослідній групі була на 0,26\% вищою порівняно 3 контрольною. В заключний період дорощування практично не спостерігалось різниці в технологічному відході поросят між групами тварин. Аналогічна тенденція відмічена і в заключний період відгодівлі, тоді як в період від 78 по 119 добу відхід поросят виявився на $0,11 \%$ серед тварин дослідної групи.
В цілому за період від відлучення до забою технологічний відхід поросят був на 0,83\% вищим у тварин 3 більш коротким підсисним періодом.

Валове споживання корму в розрізі груп (рис.5) суттєво не відрізнявся в усі періоди, за винятком першого періоду дорощування, що пов'язано насамперед з різною його тривалістю. В решті періодів життя не спостерігалось суттєвої різниці за цим показником.

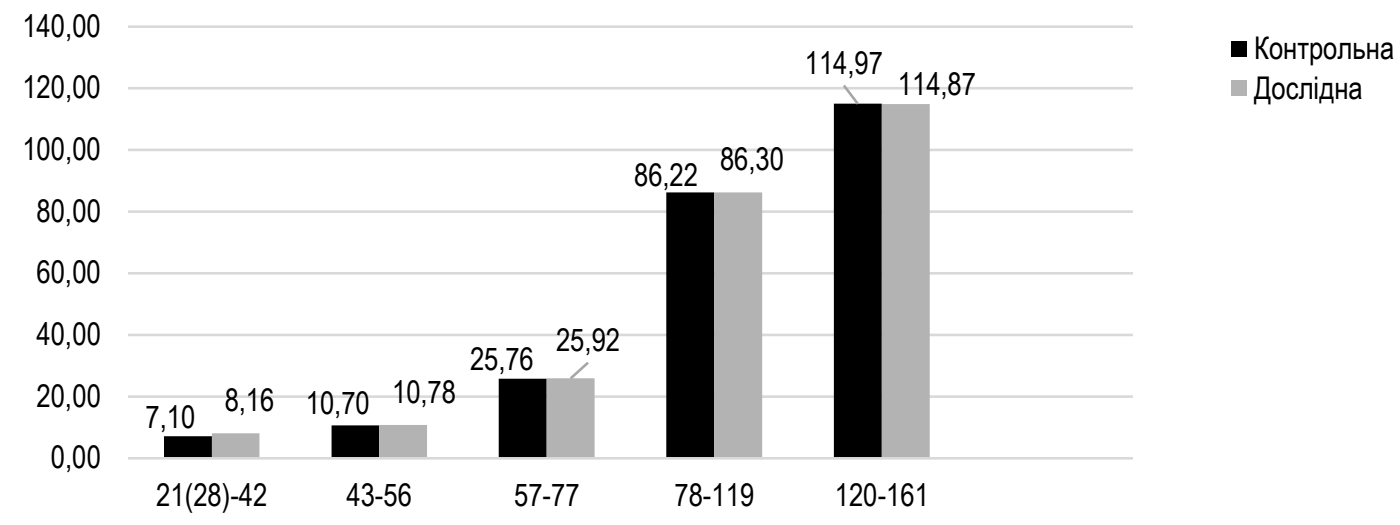

Рис.5. Динаміка споживання корму під час дорощування та відгодівлі свинями з різною тривалістю підсисного періоду

Середньодобове споживання корму також не значно $\mid$ дорощування (рис.6). відрізнялись в розрізі груп, за винятком першого періоду

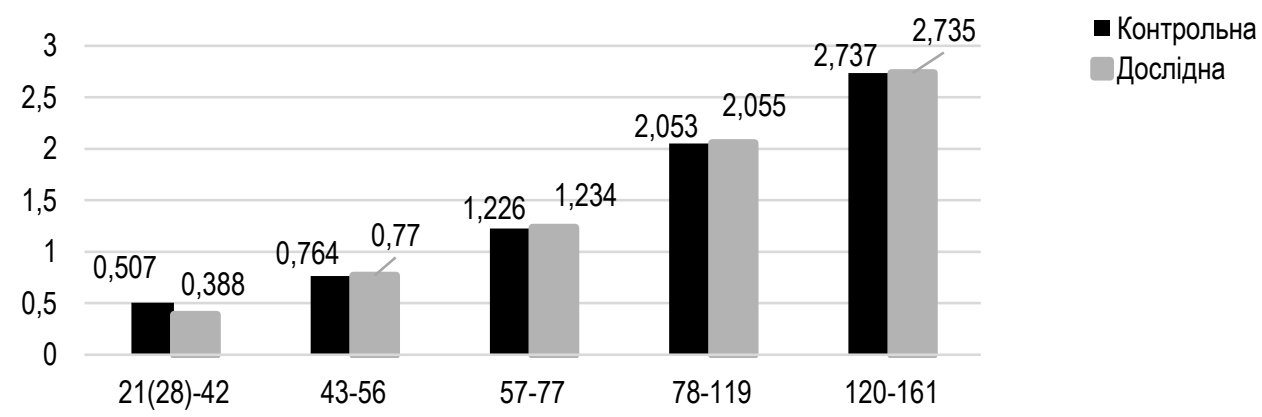

Puc.6. Динаміка середньодобового споживання корму під час дорощування та відгодівлі свинями з різною тривалістю підсисного періоду

За період, від відлучення до 42 доби, під час якого тварини вживали престартерний комбікорм, його кількість склала 0,388 кг у дослідній групі та 0,507 кг в контрольній.

Це викликано різною тривалістю цих періодів, ніж тривалістю підсисного періоду. В решту періодів після відлу- ченого періоду життя тварин різниця в щодобовому споживанні корму складала 2-8 г в розрахунку на одну голову.

Витрати корму на одиницю приросту на дорощувані та відгодівлі залежали від тривалості підсисного періоду у поросят (рис.7).

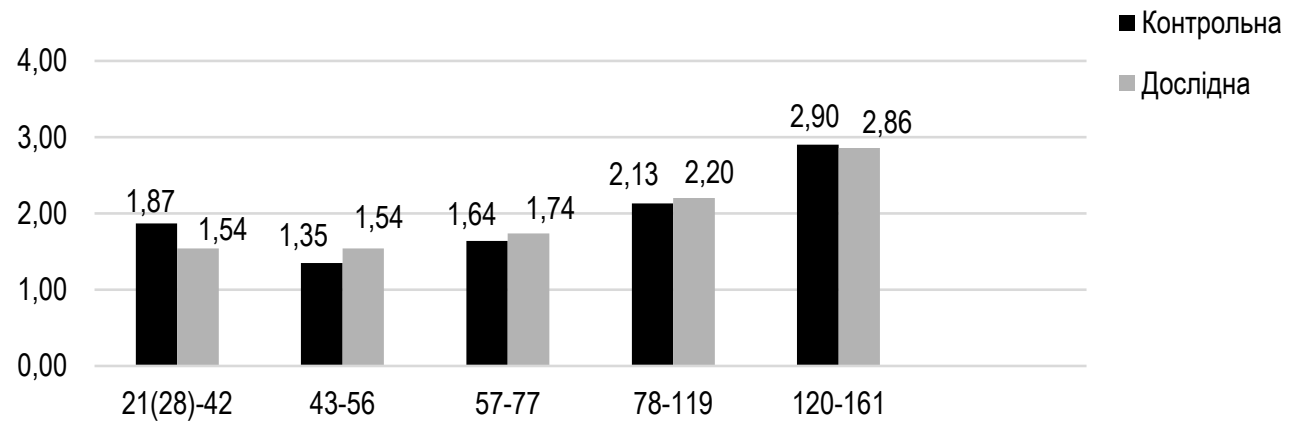

Puc.7 Динаміка витрат корму на 1 кг приросту під час дорощування та відгодівлі свинями з різною тривалістю підсисного періоду 
Так в перший період дорощування вони виявились вищими на 0,33 кг у тварин контрольної групи, але це, на наш погляд, більше пов'язано з різною тривалістю періоду дорощування ніж тривалістю підсисного періоду.

В період споживання першого стартерного комбікорму, з 43 по 56 добу, його витрати на одиницю приросту виявились на 0,19 кг вищими в дослідній групі, що, на наш погляд, пов'язано з меншою інтенсивністю росту поросят цієї групи в даний період, і як наслідок, збільшення частки підтримуючого корму. В останній період дорощування з 57 по 77 добу, інтенсивність росту поросят дещо вирівнялась, що спричинило зменшення до 0,10 кг різниці на користь контрольної групи в витратах корму на одиницю приросту.

В перший період відгодівлі інтенсивність росту свиней контрольної і дослідної групи, ще більш вирівнялась, що спричинило зменшення до 0,07 кг різниці в витратах корму на 1 кг приросту. В заключний період відгодівлі свині дослідної групи показали вищі на 15 г середньодобові прирости, що на наш погляд, спричинило кращу на 0,04 кг оплату корму.
Поросята за раннього їх відлучення мали на дорощуванні і початку відгодівлі нижчу на 2,90-11,35\% інтенсивність росту, гіршу на 0,83\% збереженість та на 0,03 кг оплату корму приростами.

Результати вивчення м'ясної продуктивності свиней, з різною тривалістю підсисного періоду (табл. 3) свідчать про незначний його вплив реалізацію їх забійних якостей. Показники забою з живою масою 100 кг у тварин з різною тривалістю підсисного періоду практично не залежали від його тривалості, а більше залежали від передзабійної живої маси. При забої в 110 кг спостерігалась аналогічна тенденція і тільки за довжиною туші встановлене перевершення на 1,50 cм $(p<0,05)$ туш свиней контрольної групи над аналогами дослідної.

При порівнянні забійних якостей свиней за різних вагових кондицій встановлено зростання всіх морфометричних показників як в контрольній, так і в дослідній групах з підвищенням передзабійної живої маси.

Отже, за результатами досліджень не встановлено залежності реалізації потенціалу забійних якостей від тривалості підсисного періоду.

Таблиця 3

Забійні якості молодняку свиней за різної тривалості підсисного періоду, $\bar{X} \pm S_{\bar{X}}$

\begin{tabular}{|c|c|c|}
\hline \multirow{2}{*}{ Показник } & \multicolumn{2}{|c|}{ Тривалість підсисного періоду, діб } \\
\hline & 28(контрольна група) & 21(дослідна група) \\
\hline \multicolumn{3}{|c|}{ при забої живою масою 100 кг, $(n=10)$} \\
\hline Передзабійна жива маса, кг & $100,8 \pm 0,33$ & $100,4 \pm 0,41$ \\
\hline Забійна маса, кг & $72,9 \pm 0,56$ & $72,9 \pm 0,63$ \\
\hline Забійний вихід, \% & $72,3 \pm 0,55$ & $72,6 \pm 0,73$ \\
\hline Товщина шпику: над 6 - 7 грудними хребцями, мм & $21,3 \pm 1,36$ & $21,1 \pm 1,52$ \\
\hline у холці & $36,5 \pm 0,84$ & $35,8 \pm 0,46$ \\
\hline на грудях & $16,4 \pm 0,69$ & $17,1 \pm 0,97$ \\
\hline на крижах & $16,0 \pm 1,21$ & $16,8 \pm 1,06$ \\
\hline Площа «м'язового вічка», см² & $39,6 \pm 0,65$ & $38,9 \pm 0,77$ \\
\hline Довжина напівтуші, см & $98,7 \pm 0,93$ & $99,1 \pm 1,17$ \\
\hline Маса задньої третини напівтуші, кг & $11,8 \pm 0,23$ & $12,1 \pm 0,32$ \\
\hline \multicolumn{3}{|c|}{ при забої живою масою 110 кг, $(n=10)$} \\
\hline Передзабійна жива маса, кг & $111,2 \pm 1,13$ & $110,8 \pm 0,1,07$ \\
\hline Забійна маса, кг & $83,7 \pm 0,47$ & $83,2 \pm 0,63$ \\
\hline Забійний вихід, \% & $75,3 \pm 0,42$ & $75,1 \pm 0,52$ \\
\hline Товщина шпику: над 6 - 7 грудними хребцями, мм & $25,7 \pm 0,62$ & $25,3 \pm 0,77$ \\
\hline у холці & $41,3 \pm 1,17$ & $42,1 \pm 1,33$ \\
\hline на грудях & $22,9 \pm 1,03$ & $22,7 \pm 0,97$ \\
\hline на крижах & $19,2 \pm 0,92$ & $19,2 \pm 1,07$ \\
\hline Площа «м'язового вічка», см² & $42,6 \pm 0,39$ & $43,1 \pm 0,42$ \\
\hline Довжина напівтуші, см & $102,6 \pm 0,42^{*}$ & $101,1 \pm 0,36$ \\
\hline Маса задньої третини напівтуші, кг & $13,33 \pm 0,16$ & $13,39 \pm 0,11$ \\
\hline
\end{tabular}

За результатами проведеної обвалки туш отриманих від свиней з різною тривалістю підсисного періоду свиней (табл. 4), не встановлено суттєвої різниці між тваринами піддослідних груп за вмістом у них м'яса, сала та кісток. Слід відмітити, що за обох термінів підсисного періоду в тушах свиней як при забої в 100 кг, так і в 110 кг, відмічено досить високий вміст м'яса і встановлено зростання його кількості з підвищенням передзабійної маси.

Таким чином, морфологічний склад туш свиней більшою мірою залежав від їхньої передзабійної живої маси, ніж від тривалості підсисного періоду.

В умовах сьогодення поряд з показниками відгодівельної продуктивності та якості туш важлива роль приділяється якості м'яса $[6,12,15]$. Це пов'язано з підвищенням попиту населення на пісну свинину, та суттєвим збільшенням втрат м'ясопереробних підприємств через погіршення технологічних властивостей м'яса. Це є наслідком суттєвого зростанням частки поголів'я свиней 3 високою енергією росту та зниженим вмістом підшкірного сала, що надходять до м'ясокомбінатів з індустріальних підприємств, і у м'ясі яких виявляються наслідки порушень автолітичних процесів дозрівання туш [15].

Аналіз результатів досліджень фрізико-хімічних та хімічних показників якості м'яса свиней отриманих від тварин з різною тривалістю підсисного періоду свідчить про відсутність їх залежності від тривалості підсисного періоду (табл. 5). Водночас простежується тенденція до підвищення вологоутримуючої здатності та покращення його забарвленості 3 
підвищенням передзабійної живої маси. Так з підвищенням iї з 100 до 110 кг вірогідно підвищилась на 2,6-5,1 ( $p<0,05$, ( $<<0,001)$ одиниць, визначених за шкалою «Pork Quality Standards» [2], забарвленість м'яса та на 2,54-3,88\% $(p<0,01, p<0,001)$ його вологоутримуюча здатність. Хоч відповідно до норм якості викладених в роботі [15,21], вологоутримуюча його здатність повинна знаходитися в межах
53-65\%, а м'ясо тварин досліджуваних груп за властивістю утримувати вологу мало значну різницю з нижньою межею норми, що складала від 12,48 до 20,60 \%. Такий її рівень $\epsilon$ негативним фактором, який спричиняє значні втратами вільної вологи при подальшому зберіганні та переробці м'ясної сировини.

\section{Морфологічний склад туш свиней}

за різної тривалості підсисного періоду, $\bar{X} \pm S_{\bar{X}}$

\begin{tabular}{|l|c|c|}
\hline \multirow{2}{*}{ Показник } & \multicolumn{2}{|c|}{ Тривалість підсисного періоду, діб } \\
\cline { 2 - 3 } & \multicolumn{2}{|c|}{21 (дослідна група) } \\
\hline \multicolumn{1}{|c|}{ при забої живою масою 100 кг, (n=10) } & $64,6 \pm 0,38$ \\
\hline $\begin{array}{l}\text { Вміст (\%) у туші: } \\
\text { м'яса }\end{array}$ & $65,5 \pm 0,73$ & $21,5 \pm 0,19$ \\
\hline сала & $20,9 \pm 0,24$ & $13,9 \pm 0,24$ \\
\hline кісток & $13,6 \pm 0,21$ & 3,01 \\
\hline Співвідношення м'ясо: сало & 3,13 & 4,65 \\
\hline Співвідношення м'ясо: кістки & 4,82 & $65,5 \pm 0,32$ \\
\hline \multicolumn{1}{|c|}{ при забої живою масою 110 кг, (n=10) } \\
\hline $\begin{array}{l}\text { Вміст (\%) у туші: } \\
\text { м'яса }\end{array} \quad 66,2 \pm 0,33$ & $20,7 \pm 0,29$ \\
\hline сала & $20,3 \pm 0,21$ & $13,8 \pm 0,21$ \\
\hline кісток & $13,5 \pm 0,17$ & 3,16 \\
\hline Співвідношення м'ясо: сало & 3,26 & 4,75 \\
\hline Співвідношення м'ясо: кістки & 4,90 & \\
\hline
\end{tabular}

Показники активної кислотності м'яса знаходились в межах фрізіологічних норм і суттєво не змінювались зі зростанням передзабійної живої маси.

Відомо, що високопродуктивні м'ясні генотипи свиней відрізняються високим вмістом протеїну в м'язовій тканині. Нашими дослідженнями встановлено досить високий вміст протеїну у м'ясі тварин як контрольної так і дослідної груп за обох вагових категорій свиней. При цьому його вміст не залежав від тривалості підсисного періоду.

Слід відмітити, що важливим показником якості м'яса, та показником його смакових якостей $є$ вміст в ньому внутрішньом'язового жиру. Його вміст в м'ясі піддослідних свиней також не залежав від тривалості підсисного періоду та мав тенденцію до збільшення з підвищенням передзабійної маси.

Показники якості м'яса туш свиней

за різної тривалості підсисного періоду, $\bar{X} \pm S_{\bar{X}}$

\begin{tabular}{|c|c|c|}
\hline \multirow{2}{*}{ Показник } & \multicolumn{2}{|c|}{ Тривалість підсисного періоду, діб } \\
\hline & 28(контрольна група) & 21(дослідна група) \\
\hline \multicolumn{3}{|c|}{ при забої живою масою 100 кг (n=10) } \\
\hline 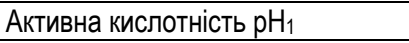 & $6,63 \pm 0,049$ & $6,73 \pm 0,051$ \\
\hline Активна кислотність $\mathrm{pH}_{24}$ & $5,60 \pm 0,040$ & $5,64 \pm 0,037$ \\
\hline Колір, Minolta $L^{*}$ & $47,8 \pm 0,84$ & $49,0 \pm 0,943$ \\
\hline Вологоутримуюча здатність, \% & $41,17 \pm 1,124$ & $40,52 \pm 1,031$ \\
\hline Загальна волога, \% & $74,19 \pm 0,136$ & $74,61 \pm 0,096$ \\
\hline Зола,\% & $1,13 \pm 0,010$ & $1,11 \pm 0,009$ \\
\hline Протеїн, \% & $23,06 \pm 0,111$ & $23,18 \pm 0,123$ \\
\hline Внутрішньо - м'язовий жир,\% & $1,62 \pm 0,107$ & $1,10 \pm 0,142$ \\
\hline \multicolumn{3}{|c|}{ при забої живою масою 110 кг $(n=10)$} \\
\hline 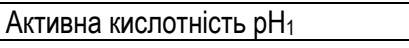 & $6,61 \pm 0,056$ & $6,69 \pm 0,061$ \\
\hline Активна кислотність $\mathrm{pH}_{24}$ & $5,65 \pm 0,023$ & $5,66 \pm 0,029$ \\
\hline Колір, Minolta $L^{*}$ & $52,9 \pm 1,17$ & $51,6 \pm 1,02$ \\
\hline Вологоутримуюча здатність, \% & $43,71 \pm 0,312$ & $44,40 \pm 0,569$ \\
\hline Загальна волога, \% & $73,92 \pm 0,121$ & $74,17 \pm 0,119$ \\
\hline Зола,\% & $1,19 \pm 0,011$ & $1,16 \pm 0,018$ \\
\hline Протеїн, \% & $24,88 \pm 0,122$ & $24,67 \pm 0,104$ \\
\hline Внутрішньо - м'язовий жир,\% & $1,71 \pm 0,194$ & $1,62 \pm 0,129$ \\
\hline
\end{tabular}

Таким чином, основні показники якості туш та фізикохімічні властивості м'яса не залежали від тривалості підсисного періоду у поросят, а мали тенденцію до змін з підвищенням передзабійної живої маси.
Висновки. 1. Скорочення з 28 до 21 доби тривалості лактації призвело до зниження багатоплідності на 7,33\%, маси гнізда поросят при народжені на 5,49\%, середньої маси одного поросяти на 23,34\%, маси гнізда при відлучені 
на $17,70 \%$, абсолютного на $28,57 \%$ та відносного на $11,08 \%$ приростів, але покращило на 6,34\% збереженість, на 7,34\% кількість поросят при відлучені, на 2,21\% їх середньодобові прирости в підсисний період та 6,25\% комплексний показник відтворювальних якостей. Збільшило на 5,35\% інтенсивність використання свиноматки, дозволило додатково отримати від неї на 13,95\% більше ділових поросят, на 25,00\% інтенсивніше використовувати станкомісце для опоросу, зменшити на 27,25\% щорічні витрати комбікорму та додатково отримати за цей період 1331 грн грошових коштів.

2. Поросята за раннього їх відлучення мали на дорощуванні і початку відгодівлі нижчу на 2,90-11,35\% інтен- сивність росту, гіршу на 0,83\% збереженість та на 0,03 кг оплату корму приростами.

3. Не встановлено залежності забійних якостей, вмісту у тушах м'яса, сала та кісток і фрізико-хімічних властивостей м'яса від тривалості підсисного періоду. Натомість виявлено залежність цих показників від їхньої передзабійної живої маси.

4. 3 урахуванням потенційного економічного ефекту від скорочення підсисного періоду рекомендуємо промисловим свинокомплексам впроваджувати відлучення поросят в віці 21 добу на товарних репродукторах.

\section{Список використаної літератури:}

1. Антоненко П.П., Свежицев А.Н., Масляк Д.Н. и др. Нормированое кормление свиней. Д.: Арт-Пресс, 2009. 360 с.

2. Баньковська І.Б. Експрес-оцінка дозрівання м'язів у тушах свиней. Продовольчі ресурси: проблеми і перспективи : зб. наук. пр. за матеріалами II Міжнар. наук.-практ. конф., 11 листопада 2014 р. Київ: Національний науковий центр « Інститут аграрної економіки», 2014. С. 188-191.

3. Баньковська І.Б. Модифікація методу визначення вологоутримуючої здатності м'яса. Сучасні методики досліджень у свинарстві. Полтава, 2005. С. 156-157.

4. Березовский Н.Д., Почерняев Ф. К., Коротков В. А. Методика моделирования индексов для использования их в селекции свиней. Методы улучшения процессов селекции, разведения и воспроизводства свиней (методические указания). М., 1986. С. 3-14.

5. Влізло В.В. Лабораторні методи досліджень у біології, тваринництві та ветеринарній медицині: довідник. за ред. В.В. Влізло. Львів: СПОЛОМ, 2012. 767 с.

6. Виноградський А.І. Раннє відлучення поросят. К.: Урожай, 1975. 64 с.

7. Вовк С.О., Кружель Б.Б., Бальковський В.В. Кожному своя якість. Порівняльна характеристика торгово-ринкової оцінки якості туш свиней у країнах Євросоюзу й України. Мясной бизнес. 2006. № 2. С. 46-47.

8. Волощук В.М. Особливості селекційно-технологічних рішень та організаційних форм у сучасному свинарстві. Свинарство. 2012. №. 61. С. 3-8.

9. Грищенко Н.П. Розвиток свинарства в Україні. Тваринництво та технології харчових продуктів. 2017. № 271. С.

10. Демиденко И.С., Походня Г. С. Влияние различных сроков отъема поросят на их рост, сохранность и воспроизводительные функции свиноматок. Материалы международной студенческой научной конференции. Белгород, 2005. 98 с.

11. Жирников Н.И. Влияние различных сроков отъема поросят на репродуктивные качества маток, рост и развитие приплода. Известия Оренбургского государственного аграрного университета. 2008. № 1(17). С. 84-86.

12. Заяс Ю.Ф. Качество мяса и мясопродуктов. Москва: Легкая и пищевая промышленность, 1981. 480 с.

13. Иванкин А.Н., Гузнецова Т.Г. Современные методы оценки качества и безопасности сырья и мясопродуктов. Все о мясе. 2005. № 4. С. 26-30.

14. Иванова Н.В. Ранний отьем поросят и интенсивность использувания маток. Сборник III Всероссийской (национальной) научной конференции. Новосибирск, 2018. С. 352-353.

15. Канюка О.Ю. Рівень фізико-хімічних показників м'яса свиней великої білої породи за останні 40 років. Свинарство: міжв. темат. наук. збірник. Полтава, 2012. Вип. 60. С. 137-141

16. Криштафович В.И. и др. Потребительские свойства мяса с отклонениями в процессе автолиза. Мясная индустрия. 2007. № 5. С. 30-34.

17. Кузьменко М.В. Ефективність відгодівлі молодняку свиней за різної початкової маси. Вісник аграрної науки. 2012. №. 12. С. $77-78$.

18. Ленина В.И. Повышение эффрективности использования маточного стада свиней. Всесоюзн. акад. С.-Х. наук им. В. И. Ленина. М: Колос, 1983. 179 с.

19. М'ясо та м'ясні продукти. Визначення рН (контрольний метод) (ISO 2917:1999, IDT): ДСТУ ISO 2917:2001. [Чинний від 2003-01-01]. Київ: Державний комітет України з питань технічного регулювання та споживчої політики 2002. 6 с. (Національний стандарт України).

20. М'ясо. Свинина в тушах і півтушах. Технічні умови: ДСТу 7158:2010. [Чинний від 2011-01-01]. Київ: Держспоживстандарт України 2010. 11 с. (Національний стандарт України).

21. Мясо и мясные продукты. Методы определения жира ГОСТ 23042-86. [Срок действия с 1988-01-01. Проверено 2012-07-30]. Москва Государственный комитет СССР по стандартам. 9 с.

22. Немченко В.В. Продовольча безпека України. Збірник наукових праць ВНАУ. 2012. Т. 2. № 4.70 с.

23. Поливода А.М., Стробыкина Р.В., Любецкий М.Д. Методика оценки качества продуктов убоя у свиней. Методики исследований по свиноводству. Харьков, 1977. С. 48-56.

24. Походня Г.С., Корниенко П.П., Малахова Т.А,. Кренева Т.В., Маменко А.М. Эфффективность выращивания поросят при различных сроках их отъёма. Проблеми зооінженерії та ветеринарної медицини. 2017. № 33 (1). С. 129-134.

Вісник Сумського національного аграрного університету 
25. Стрельцов В.А., Лавров В.В. Естественная резистентность у поросят при различных сроках отъема. Материалы Международной научно-практической конференции, посвященной 75-летию со дня рождения и 50-летию трудовой деятельности Заслуженного деятеля науки РФ, Заслуженного ученого Брянской области, Почетного профессора Брянского ГАУ, доктора сельскохозяйственных наук, профессора Гамко Леонида Никифоровича . Кокино, 2016. С. 280-283.

26. Творогова Е.В. Экономические предпосылки внедрения технологии сверхраннего отъема поросят. Вестник Чувашского государственного педагогического университета им. И. Я. Яковлева. 2013. № 2 (78). С. 159-162.

27. Христофор Л.Х. Влияние срока отъема поросят на продуктивность и воспроизводительные качества свиноматок в условиях Якутии: автореф. дис. на здобуття наук. ступеня канд. с.-г. наук: спец. 06.02.04 "Ветеринарная хирургия. Якут. гос. с.-х. акад., 2006. 19 с.

28. Campbell, J.M., Crenshaw, J.D. and Polo, J., 2013. The biological stress of early weaned piglets . Journal of animal science and biotechnology, vol. 4, issue 1, p. 19.

29. Colson, V., 2012. Influence of housing and social changes on growth, behaviour and cortisol in piglets at weaning. Physiology \& behavior, vol. 107, issue 1, pp. 59-64.

30. Colson, V., Orgeur, P., Foury, A. and Mormède, P., 2005. Consequences of weaning piglets at 21 and 28 days on growth, behaviour and hormonal responses. Applied Animal Behaviour Science, issue 98, pp. 70-88.

31. Jarvis, S., 2008. Effects of weaning age on the behavioural and neuroendocrine development of piglets. Applied Animal Behaviour Science, vol. 110, issue 1-2, pp. 166-181.

32. Leibbrandt, V.D., Ewan, J. R.C. and Zimmerman D.R., 1975 Effect of weaning and age at weaning on baby pig performance. Animal Science, issue 40, pp. 1077-1080.

33. Marin, D., 2012. Nursing management and its impact on weaned piglet weight. Porcine Research, vol. 2, issue 1, pp. 2326.

34. Peet, B., 2003. Is it time to re-assess your weaning age? Western Hog Journal. Sheffield: Benchmark House, Available at: URL:http//www.thepigsite.com/articles/807/is-it-timeto-reassess-your-weaning-age [Accessed 8 February 2020].

35. Turpin, D.L., Langendijk, P., Chen, T.Y. and Pluske J.R., 2016. Intermittent Suckling in Combination with an Older Weaning Age Improves Growth, Feed Intake and Aspects of Gastrointestinal Tract Carbohydrate Absorption in Pigs after Weaning. Animals (Basel), issue. 6(11), p. 6. doi:10.3390/ani6110066.

36. Whiting, T. and Pasma, T., 2008. Isolated weaning technology: humane benefits and concerns in the production of pork. The Canadian veterinary journal, issue 49, pp. 293-301.

37. Worobec, E. and Duncan, E., 1997. Early weaning in swine: A behavioral review. Compendium on Continuing Education for the Practicing Veterinarian, issue 19, pp. 271-277.

\section{References:}

1. Antonenko, P.P., Svezhicev, A.N., Masljak, D.N., 2009. Normirovanoe kormlenie svinej [Normalized Feeding Pigs]. D. Art-Press, p. 360.

2. Bankovska, I.B., 2014. Ekspres-otsinka dozrivannia miaziv u tushakh svynei. [Rapid evaluation of muscle maturation in pig carcasses]. Prodovolchi resursy: problemy i perspektyvy, pp. 188-191.

3. Bankovska, I.B., 2005. Modyfikatsiia metodu vyznachennia volohoutrymuiuchoi zdatnosti miasa. [Modification of the method for determining water-retaining capacity of the meat]. Suchasni metodyky doslidzhen u svynarstvi. Poltava, pp. 156-157.

4. Berezovskij, N.D., Pochernjaev, F.K. and Korotkov, V.A., 1986. Metodika modelirovanija indeksov dlja ispol'zovanija ih v selekcii svinej [Method of modeling indices for use in breeding pigs]. Metody uluchshenija processov selekcii, razvedenija $i$ vosproizvodstva svinej (metodicheskie ukazanija). pp. 3-14.

5. Vlizlo, V.V., 2012. Laboratorni metody doslidzhen u biolohii, tvarynnytstvi ta veterynarnii medytsyni, [Laboratory Research Methods in Biology, Livestock and Veterinary Medicine: A Handbook]. dovidnyk. V.V. Vlizlo, p. 767.

6. Vynohradskyi A.I., 1975. Rannie vidluchennia porosiat [Early weaning of piglets]. Kiev. Urozhai, p. 64.

7. Vovk, S.O., Kruzhel, B.B. and Balkovskyi, V.V., 2006. Kozhnomu svoia yakist. Porivnialna kharakterystyka torhovorynkovoi otsinky yakosti tush svynei u krainakh Yevrosoiuzu y Ukrainy [Each has its own quality. Comparative characteristics of trade and market assessment of the quality of pig carcasses in EU countries and Ukraine]. Miasnoi byznes, issue 2, pp. 46-47.

8. Voloshchuk, V.M., 2012. Osoblyvosti selektsiino-tekhnolohichnykh rishen ta orhanizatsiinykh form u suchasnomu svynarstvi [Features of breeding-technological solutions and organizational forms in modern pig breeding]. Svynarstvo, issue 61, pp. 3-8.

9. Hryshchenko, N.P., 2017. Rozvytok svynarstva v Ukraini [Development of pig breeding in Ukraine]. Tvarynnytstvo ta tekhnolohii kharchovykh produktiv, issue 271, pp. 16-23.

10. Demidenko, I.S. and Pohodnja, G.S., 2005. Vlijanie razlichnyh srokov otema porosjat na ih rost, sohrannost' i vosproizvoditel'nye funkcii svinomatok [The effect of different weaning periods on pigs' growth, conservation and reproductive function]. Mat. mizhd studen nauk. konf. Belgorod, p. 98.

11. Zhyrnykov, N.Y., 2008. Vlyianye razlychnikh srokov otjema porosiat na reproduktyvnie kachestva matok, rost y razvytye pryploda [The effect of different weaning periods on the reproductive quality of the uterus, growth and development of the offspring]. Yzvestyia Orenburhskoho hosudarstvennoho ahrarnoho unyversyteta, issue 1 (17), pp. 84-86.

12. Zajas, J.F., 1981. Kachestvo mjasa i mjasoproduktov [The quality of meat and meat products]. Moskva: Legkaja $i$ pishhevaja promyshlennost, p. 480. 
13. Zlvankin, A.N., and Guznecova T.G., 2005. Sovremennye metody ocenki kachestva i bezopasnosti syr'ja i mjasoproduktov [Modern methods for assessing the quality and safety of raw materials and meat products]. Vse o mjase, issue 4, pp. 26-30.

14. Ivanova, N.V., 2018. Rannij ot'em porosjat i intensivnost' ispol'zuvanija matok [Early weaning and intensity of use of queens]. Sbornik III Vserossijskoj (nacional'noj) nauchnoj konferencii. Novosibirsk, pp. 352-353.

15. Kaniuka, O.Y., 2012. Riven fizyko-khimichnykh pokaznykiv miasa svynei velykoi biloi porody za ostanni 40 rokiv [The level of physico-chemical parameters of pig meat of large white breed over the last 40 years]. Svynarstvo: mizhv. temat. nauk. zbirnyk. Poltava, issue 60, pp. 137-141.

16. Krishtafovich, V.I., 2007. Potrebitel'skie svojstva mjasa s otklonenijami v processe avtoliza [Consumer properties of meat with deviations in the process of autolysis]. Mjasnaja industrija, issue 5, pp. 30-34.

17. Kuzmenko, M.V., 2012. Efektyvnist vidhodivli molodniaku svynei za riznoi pochatkovoi masy [Effectiveness of fattening pigs young at different starting weight]. Visnyk ahrarnoi nauky, issue 12, pp. 77-78.

18. Lenina, V.I., 1983. Povyshenie jeffektivnosti ispol'zovanija matochnogo stada svinej [Improving the efficiency of use of the uterine herd of pigs]. Vsesojuzn. akad. s.-h. nauk im. V. I. Lenina. M.: Kolos, p. 179.

19. State Committee for Technical Regulation and Consumer Policy, 2001. DSTU ISO 2917:2001 Meat and meat products. Determination of $\mathrm{pH}$ (control method). Kyiv: State Committee of Ukraine for Technical Regulation and Consumer Policy.

20. State Committee for Technical Regulation and Consumer Policy, 2010. DSTU 7158:2010 Meat. Pork in carcasses and half carcasses. Specifications. Kyiv: State Committee for Technical Regulation and Consumer Policy.

21. USSR State Committee for Standards, 1986. GOST 23042-86 Meat and meat products. Methods for determining fat. Moscow: USSR State Committee for Standards.

22. Nemchenko, V.V., 2012. Prodovolcha bezpeka Ukrainy [Food security of Ukraine]. Zbirnyk naukovykh prats VNAU, vol. 2, issue 4, p. 70.

23. Polivoda, A.M., Strobykina, R.V. and Ljubeckij M.D., 1977. Metodika ocenki kachestva produktov uboja u svinej [Methodology for assessing the quality of slaughter products in pigs]. Metodiki issledovanij po svinovodstvu. Har'kov, pp. 48-56.

24. Pohodnja, G.S., Kornienko, P.P., Malahova, T.A,. Kreneva, T.V. and Mamenko A.M., 2017. Jeffektivnost' vyrashhivanija porosjat pri razlichnyh srokah ih otjoma [The effectiveness of growing pigs at different periods of weaning]. Problemi zooinzhenerii ta veterinarnoï medicini. issue 33(1), pp. 129-134.

25. Strel'cov, V.A. and Lavrov, V.V., 2016. Estestvennaja rezistentnost' u porosjat pri razlichnyh srokah otema [Natural resistance in piglets at different weaning periods]. Mat. mizhd studen nauk. prakt. konferencii, Brjanskogo GAU, Kokino, pp. $280-283$.

26. Tvorogova, E.V., 2013. Jekonomicheskie predposylki vnedrenija tehnologii sverhrannego otjema porosjat [Economic prerequisites for introducing technology of early weaning piglets.]. Vestnik Chuvashskogo gosudarstvennogo pedagogicheskogo universiteta im. I. Ja. Jakovleva. issue 2 (78), pp. 159-162.

27. Hristofor, L.H., 2006. The influence of the weaning period of piglets on the productivity and reproductive quality of sows in the conditions of Yakutia. Abstract of Ph.D. dissertation. Jakut. gos. s.-h. akad. p. 19.

28.Campbell, J.M., Crenshaw, J.D. and Polo, J., 2013. The biological stress of early weaned piglets . Journal of animal science and biotechnology, vol. 4, issue 1, p. 19.

29.Colson, V., 2012. Influence of housing and social changes on growth, behaviour and cortisol in piglets at weaning. Physiology \& behavior, vol. 107, issue 1, pp. 59-64.

30.Colson, V., Orgeur, P., Foury, A. and Mormède, P., 2005. Consequences of weaning piglets at 21 and 28 days on growth, behaviour and hormonal responses. Applied Animal Behaviour Science, issue 98, pp. 70-88.

31.Jarvis, S., 2008. Effects of weaning age on the behavioural and neuroendocrine development of piglets. Applied Animal Behaviour Science, vol. 110, issue 1-2, pp. 166-181.

32.Leibbrandt, V.D., Ewan, J. R.C. and Zimmerman D.R., 1975 Effect of weaning and age at weaning on baby pig performance. Animal Science, issue 40, pp. 1077-1080.

26.

33.Marin, D., 2012. Nursing management and its impact on weaned piglet weight. Porcine Research, vol. 2, issue 1, pp. 23-

34.Peet, B., 2003. Is it time to re-assess your weaning age? Western Hog Journal. Sheffield: Benchmark House, Available at: URL:http//www.thepigsite.com/articles/807/is-it-timeto-reassess-your-weaning-age [Accessed 8 February 2020].

35.Turpin, D.L., Langendijk, P., Chen, T.Y. and Pluske J.R., 2016. Intermittent Suckling in Combination with an Older Weaning Age Improves Growth, Feed Intake and Aspects of Gastrointestinal Tract Carbohydrate Absorption in Pigs after Weaning. Animals (Basel), issue. 6(11), p. 6. doi:10.3390/ani6110066.

36.Whiting, T. and Pasma, T., 2008. Isolated weaning technology: humane benefits and concerns in the production of pork. The Canadian veterinary journal, issue 49, pp. 293-301.

37.Worobec, E. and Duncan, E., 1997. Early weaning in swine: A behavioral review. Compendium on Continuing Education for the Practicing Veterinarian, issue 19, pp. 271-277. 


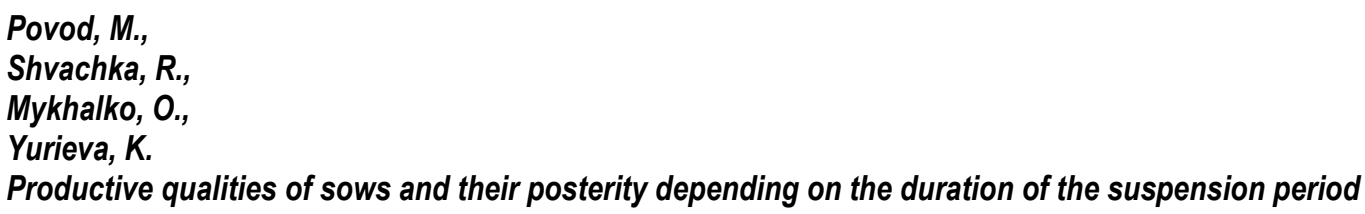

The Article examined the dependence of reproductive, feeding, slaughtering properties and physical and chemical indicators of meat on duration of sucking period in pigs of modern intensive genotypes. It was found that shortening of lactation period from 28 to 21 days resulted in decrease of total number of piglets born by $6.28 \%$, fertility by $7.33 \%$, piglets' litter weight at birth by $5.49 \%$, average weight of one piglet by $2334 \%$, litter weight during this period by $17.70 \%$, absolute by $28.57 \%$ and relative by 11.08 gains, and the increase by $1.49 \%$ of fertility, by $6.34 \%$ the viability by $7.34 \%$ of the number of piglets when weaned, by $2.21 \%$ of their daily average gains in the feeding period and $6.25 \%$ of the complex index of reproductive qualities. At the same time reduction of lactation period of sows by 7 days increased the use rate of sow by $5.35 \%$ which additionally allowed to get from it by $13.95 \%$ more business piglets, by $25 \%$ use the farrowing crate more intensively, decrease by $27.25 \%$ annual costs of animal feed and additionally to receive UAH 1,331 of cash during this period. At early weaning, the piglets had by $2.90 \%-11.35 \%$ lower growth rate, a by $0.83 \%$ worse viability rate, and by $0.03 \mathrm{~kg}$ increase in feed efficiency at the time of their nursing and feeding. There is no dependence of slaughtering properties, content of meat, lard and bones in carcasses and physical and chemical properties of meat on duration of sucking period. Their dependence on pre-slaughter body weight was found.

Key words: sow, piglet, gain, fertility, viability, feed efficiency, use rate

Дата надходження до редакції: 19.10.2019 р. 